\title{
A step-by-step framework to assess benefits of established temperate marine protected areas
}

AUTHORS:

Albrecht Götz

Sven E. Kerwath ${ }^{2,3}$

Colin G. Attwood ${ }^{3}$

\section{AFFILIATIONS:}

${ }^{1}$ Elwandle Node, South African Environmental Observation

Network, Grahamstown, South Africa

${ }^{2}$ Department of Agriculture, Forestry and Fisheries, Cape Town, South Africa

${ }^{3}$ Department of Zoology, University of Cape Town, Cape Town, South Africa

\section{CORRESPONDENCE TO:}

Albrecht Götz

EMAIL:

albrecht@saeon.ac.za

POSTAL ADDRESS: Elwandle Node, South African Environmental Observation Network, Private Bag 1015, Grahamstown 6140, South Africa

\section{DATES:}

Received: 24 Apr. 2012

Revised: 13 July 2012

Accepted: 22 July 2012

\section{KEYWORDS:}

conservation; fisheries management; spillover; Goukamma Marine Protected Area; temperate reef fish; South Africa

\section{HOW TO CITE:}

Götz A, Kerwath SE, Attwood CG. A step-by-step framework to assess benefits of established temperate marine protected areas. S Afr J Sci. 2013:109(1/2), Art. \#1243, 9 pages. http://dx.doi.org/10.1590/ sajs.2013/1243

(c) 2013. The Authors. Published under a Creative Commons Attribution Licence.
Marine protected areas (MPAs) have been advocated as a solution to the challenges of both conservation and modern fishery management, but their application remains controversial, partly because there are only general guidelines for evaluating their effectiveness. We propose a framework to specifically evaluate established MPAs in six steps. We tested the approach by reviewing published research and unpublished information on the Goukamma MPA in the centre of the South African temperate south coast. Information reviewed included effects on the structure of fish populations, catch and abundance indices of fish species, and ecosystem effects. We investigated factors that determine the usefulness of a MPA in fisheries management, including the movement behaviour of adult fishes, larval dispersal and fisher-displacement patterns. We found that differences in the rates of exploitation across the MPA border resulted in differences in abundance, size and condition of the main target species, roman (Chrysoblephus laticeps). The diversity and abundance of non-target fish species, and the composition of the benthic invertebrate community, were affected by the cessation of fishing. The potential for 'spillover' of adult roman might be limited to the vicinity of the MPA by their small home range, but there is potential for self-seeding and dispersal of roman eggs and larvae over wider areas. These theoretical considerations were confirmed by an analysis of catch data from before and after MPA implementation. The framework presented here may help to identify and fill gaps in the knowledge of established MPAs along South Africa's temperate south coast.

\section{Introduction}

Marine protected areas (MPAs) have long been advocated as a marine conservation strategy and, more recently, as a way to address the global crisis in fisheries management. ${ }^{1-7}$ In the fisheries context it is now considered best practice to delineate MPAs based on multi-criteria optimisation algorithms and spatial data ${ }^{8-10}$ and to evaluate the effects of such areas, along with other fishery regulations, by way of computer simulations that take uncertainties into account. ${ }^{11}$ However, many of the existing MPAs were declared in response to strong motivations for coastal protection, but often without habitat and resource surveys, and without analyses on the potential impacts on fisheries. The early advocacy amounted to calls to implement MPAs quickly to stem the decline in resources, and not to delay such action for want of better information. ${ }^{3}$ As a result, the majority of evaluations of the effectiveness of MPAs were conducted post hoc, and relied on cross-boundary comparisons. As opposed to time-series studies such as 'before-after' assessments, cross-boundary comparisons are troubled by certain biases pertaining to the comparability of sites ${ }^{12}$ and the fact that abundance changes are determined relative to exploited sites. These relative changes can be misleading because they do not necessarily reflect absolute abundance increases. ${ }^{13}$

MPAs can be beneficial for the protection and recovery of fish populations and in the conservation of ecosystem functioning, ${ }^{14-16}$ but their application in fisheries management is still the subject of debate. ${ }^{17,18}$ To be considered as a viable tool for fisheries management, it has to be convincingly demonstrated that the existence of a MPA or MPAnetwork can: (1) serve as an insurance against recruitment failure by protecting enough spawning fish and (2) enhance the fished areas by exporting fish and larvae. These benefits have to outweigh possible negative effects of the MPA for the fishers, such as loss of fishing grounds and increased travel distance, which may result in a reduction of catches. ${ }^{19-21}$ However, rigorous empirical studies on the effectiveness of MPAs with regard to extracting fisheries are still scarce. ${ }^{22,23}$ Arguments for and against MPAs are mostly based on theoretical considerations. ${ }^{17}$

The evidence for success and failure of MPAs is often drawn from case studies that are rarely directly comparable because the assessed MPAs differed in size, habitats, climatic regions and management objectives. Results of modelling exercises commonly applied in the fisheries assessment context are often incompatible with results from field studies on animal behaviour and ecology, adding to the confusion surrounding the current debate, although there have been recent efforts to reconcile conservation and fisheries-related MPA research. ${ }^{24}$

Testing the effectiveness of a MPA requires a suite of biological, ecological, oceanographic and socio-economic studies that quantify spatial and temporal differences in fish and fisher populations, ecosystems and habitats. We argue that individual studies in any of these fields cannot be conclusive, but a combination of multiple welldesigned studies has the potential to provide measurable criteria on the conservation and fishery benefits of a particular MPA or MPA network.

Building on recent literature on the subject ${ }^{12,17,21,23,24}$ and experiences from our own work, ${ }^{25-30}$ we present a simple, step-by-step framework for the assessment of existing MPAs in temperate South Africa against major fisheries management and biodiversity conservation objectives (Figure 1).

We confine ourselves to these measurable ecological quantities and do not consider criteria that fall in cultural or sociological context (e.g. traditions, beliefs, aesthetic values, ethics), but we do recognise that these issues can play an important part in MPA implementation and management considerations in both the fisheries and conservation context. Also, the framework does not provide for an assessment of management efficiency ${ }^{31-33}$ and the socioeconomic considerations ${ }^{34}$ were restricted to fisheries benefits. As opposed to more general frameworks, ${ }^{35,36}$ we focused on a geographic region to provide a framework that is specifically designed for that region, detailed in its 


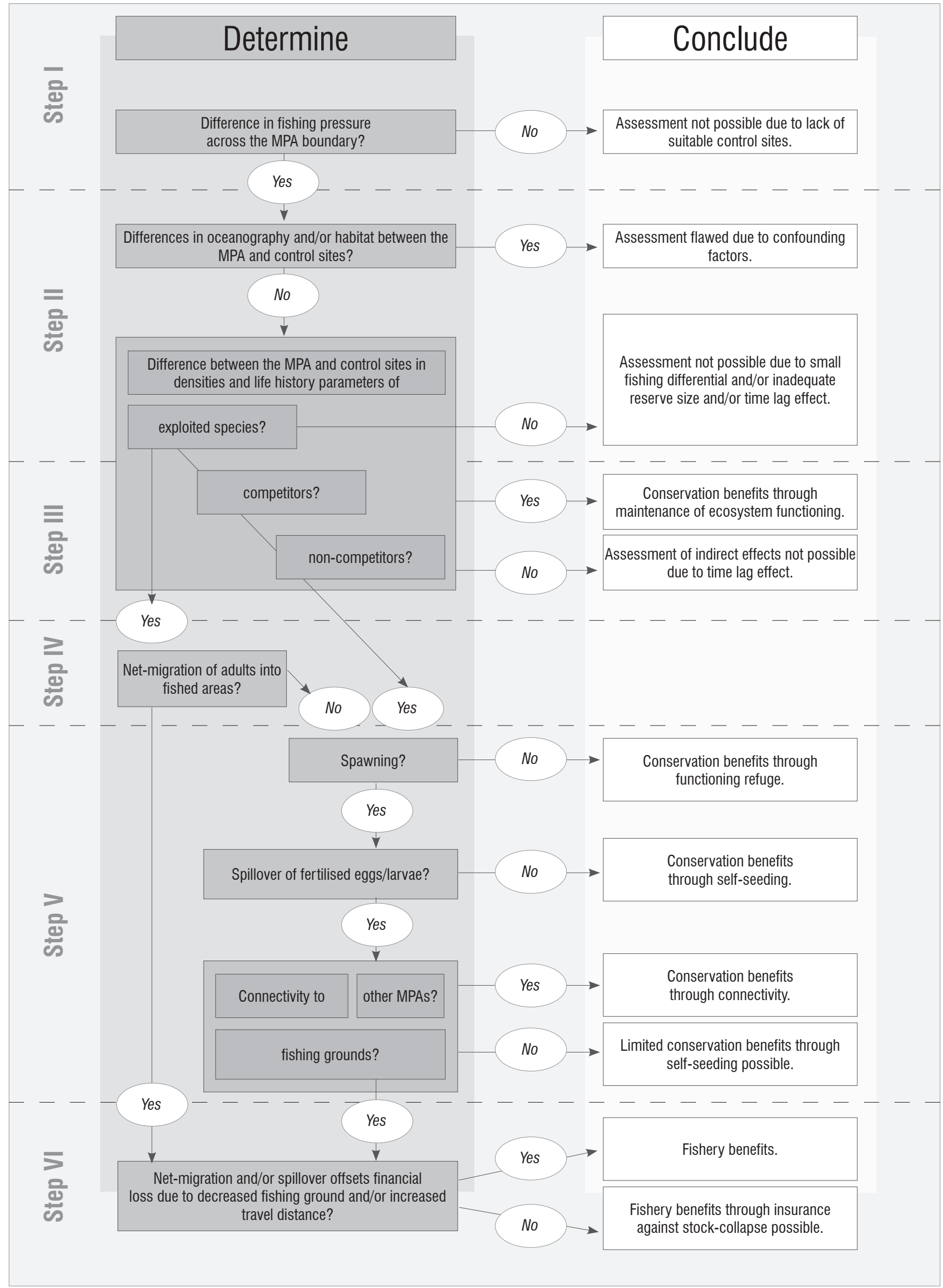

Figure 1: The marine protected area (MPA) assessment 'tool box' summarises and relates the criteria necessary to evaluate the effectiveness of a MPA in six consecutive steps. 
methodology and thoroughly tested with a case study. As a result, the developed framework should be applicable to other MPAs in that region, which could be assessed in an effective and comparable manner.

We used our framework to assess the Goukamma MPA in terms of both biodiversity conservation and fishery benefits. In the process we reviewed published information pertaining to individual assessment criteria. We chose the medium-sized Goukamma MPA as a test case because (1) it has both conservation and fisheries management objectives, (2) information on most of the above criteria were available, and (3) its central location on the south coast makes it representative of temperate reef habitat in South Africa. We define 'MPA' in this paper as an area where the exploitation of one or more species has been excluded. Goukamma was proclaimed for the protection of offshore reefs, but shore angling was allowed in the MPA, so our assessment of its effectiveness was restricted to the offshore areas. The only type of offshore exploitation occurring in the Goukamma area was boat-based linefishing. Trawling did not occur and effects of pollution or shipping were considered negligible.

\section{Test case: Goukamma}

The Goukamma MPA is situated along the temperate south coast of South Africa. It extends about $18 \mathrm{~km}$ alongshore and one nautical mile $(1.8 \mathrm{~km})$ offshore, with a total area of approximately $40 \mathrm{~km}^{2}$ (Figure 2). It includes rocky platforms, sandy beaches, an estuary (the Goukamma River), sub-tidal rocky reefs of aeolianite or sandstone origin, ${ }^{37}$ and subtidal sandy and muddy substrata. ${ }^{38}$ The MPA was implemented in 1990 for the protection of offshore reef habitats.

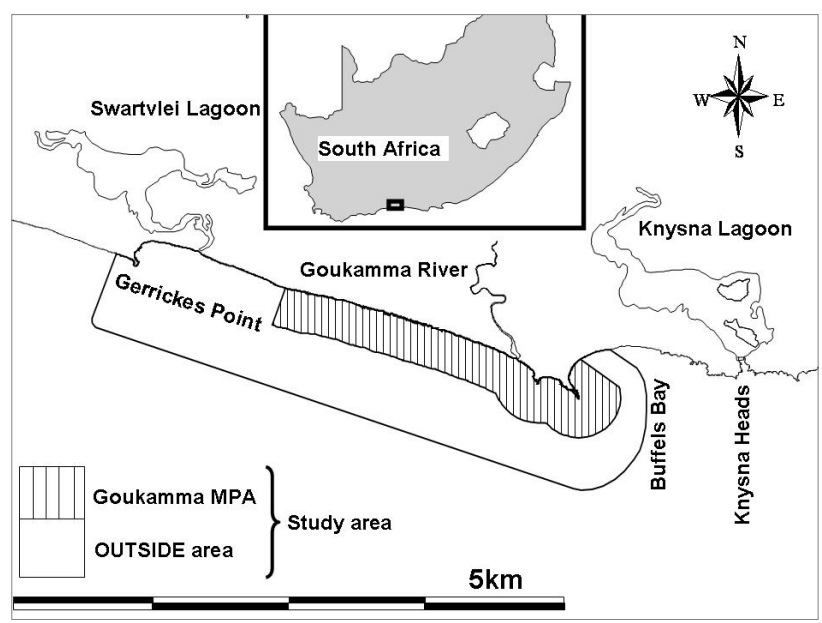

Figure 2: The Goukamma marine protected area (MPA) on the South African temperate south coast.

The offshore reefs in and around the Goukamma MPA provide habitat for a number of endemic temperate fish species. Sea breams (Sparidae) are the overwhelmingly dominant family and roman (Chrysoblephus laticeps) is the most commonly caught reef fish adjacent to the MPA. Roman grow slowly, reach a maximum age of about 19 years and sexual maturity at about 3.5 years old. As a protogynous hermaphrodite, they change sex from female to male at about 9 years old. ${ }^{27}$ They are omnivorous throughout their life but increase the fish component in their diet as they grow older and more territorial. ${ }^{26,39}$ Roman occur to a depth of $200 \mathrm{~m}$ along the temperate coast of South Africa and are represented in at least 10 MPAs in the Agulhas Bioregion. The Goukamma MPA represents less than $1 \%$ of the available habitat for this species.

The offshore reefs surrounding the Goukamma MPA are exploited by recreational and commercial fishers, who operate from motorised boats. Generally, their gear includes fibreglass rods and reels, monofilament or braded lines, chemically sharpened hooks, echo sounders and global positioning systems. Apart from roman, santer (Cheimerius nufar), blue hottentot (Pachymetopon aeneum), red stumpnose (Chrysoblephus gibbiceps) and red steenbras (Petrus rupestris) are commonly part of the reef fish catch in the area. Since 1985, commercial linefish catch and effort data have been collected by the government agency responsible for the management of marine living resources in South Africa. Based on boat skippers' estimates, the information includes daily catch in kilograms per species per boat, number of crew, hours fished, unique vessel code, year, month, date, area and approximate distance from shore.

Although shore angling is allowed inside the Goukamma MPA, the catch differs distinctly from that of the boat-based reef fishery. The eight most commonly caught fishes on offshore reefs comprised over $91 \%$ of the boat-based catch in numbers. Only four of these species were recorded in shore angling catches in Goukamma, contributing a mere $1.7 \%$ in numbers. ${ }^{40} \mathrm{As}$ a result, the shore fishery was considered to have a negligible effect beyond the surf zone.

The Goukamma MPA was implemented without rigorous testing or offshore habitat surveys. Ten years after its proclamation, a number of post-hoc fishery independent studies were conducted over a 4-year period to evaluate the MPAs benefit to conservation and its effect on the fishery. ${ }^{25-30}$ These studies were confined to offshore reef habitats in and around the Goukamma MPA which was proclaimed for the protection of overexploited offshore reef fish communities. Effects of fishing on hake (Merluccius capensis), the main linefish target on the soft substrates in the area, were not the focus of investigations and were omitted from the framework because the impact of the handline fishery on this species is negligible in comparison to the trawl sector ${ }^{41}$ and the habitat available inside the MPA is mostly too shallow for this species.

\section{Step I: Assessing differences in exploitation pressure}

The first condition, not only for the assessment but also for any meaningful function of a MPA, is that there is a significant difference in actual exploitation rates inside and outside the MPA. A lack thereof precludes an assessment of a MPA against control sites. Two reasons for this situation are plausible. The first is poor enforcement and compliance. Although the spectrum of MPAs around the world ranges from mere 'paper-parks' to areas with strict monitoring and control, we argue that there are few MPAs with a 100\% compliance rate. ${ }^{42-47}$ Many MPAs suffer from considerable illegal exploitation, sometimes purely as a result of poorly demarcated boundaries. ${ }^{48,49}$ The second is that the areas adjacent to the MPA are only lightly exploited. In some cases MPAs tend to be placed in more remote areas less important for fishers to ease implementation against public resistance. ${ }^{45}$ Both of these issues need to be investigated to provide conclusive evidence of MPA benefits.

\section{Test case: Goukamma}

Monitoring of the positions of fishing boats ${ }^{50}$ over 3 years revealed that fishing often occurred close to the MPA boundary, but seldom exceeded $500 \mathrm{~m}$ into the MPA (Figure 3). A significant difference in the average boat count between the MPA core and the fished area (seven outside for every one boat inside the MPA) was found (chi-square test; $p<0.001$ ).

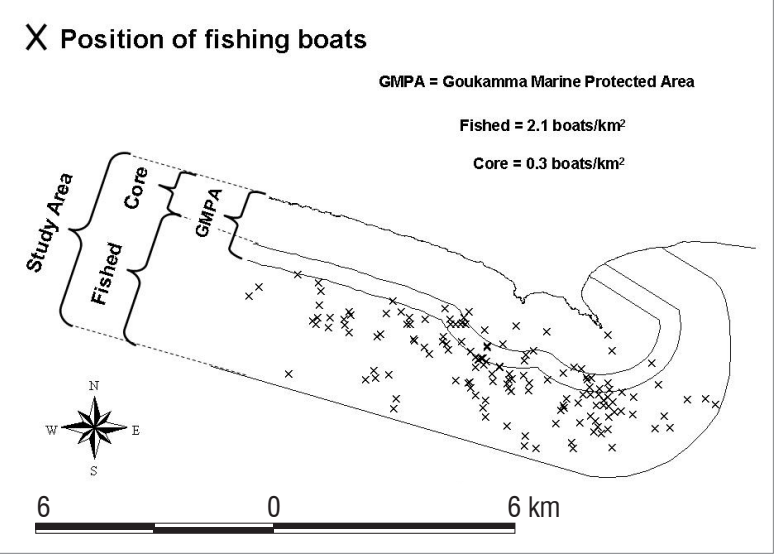

Figure 3: Positions of fishing boats in relation to the marine protected area boundary. 
Although fishing effort concentration along the boundary of a MPA is a common phenomenon ('fishing the line'), ${ }^{22,51,52}$ the frequency of transgressions or level of illegal fishing inside a MPA is usually not determined in MPA studies. This omission makes it difficult to compare the fishing differential at Goukamma to other MPAs and to predict an effect on fish abundance. However, at geographically separate fishing locations in the Caribbean, a fishing differential similar to that found at Goukamma was sufficient to produce significant changes in abundance, size and assemblage of eight species of parrotfish. ${ }^{53}$

\section{Step II: Detecting a difference in population parameters}

If spatial protection is providing any advantage to exploited species, there should be a measurable difference in abundance and/or size or other life-history parameter. This effect can be detected either as an improvement over time in the case of a newly established MPA over and above the natural variability and variability in exploitation rates, ${ }^{16,54}$ or as a difference in these parameters across the MPA boundary in the case of established MPAs, where 'before-after' studies are not possible. In such cases, it must be demonstrated that cross-boundary differences are not just the result of systematic bias in habitat, seasonality or other auxiliary factors (confounding factors), but can be ascribed to differential rates of exploitation. A failure to detect cross-boundary effects could be attributed to a small fishing differential (low exploitation levels or frequent poaching), inadequate MPA size in relation to the home range of the exploited species (too many fish become available to the fishery outside the MPA because of a large home range) or a lag-phase effect. On average, it takes at least 5 years before a reserve effect can be detected. ${ }^{13}$

\section{Test case: Goukamma}

Very little information was available on fish density, life history of the target species and the habitats inside and across the Goukamma MPA boundary before implementation. A continuous band of reef runs parallel to the coast straddling the offshore boundary of the MPA. ${ }^{30}$ Reef structure inside and outside the protected area was similar in terms of depth range, relief and rugosity. Current measurements implied that there were no systematic differences in current patterns over the reef complex as a result of fast shifting eastward $(60 \%)$, westward $(30 \%)$ or southward $(10 \%)$ currents. ${ }^{29} \mathrm{~A}$ preliminary investigation into the catches of the boat-based linefishery revealed that roman constituted the most important target species on the reef in the area. This species also constituted the most common catch of a high-value species during preliminary research angling.

Controlled angling (273 sites) and underwater visual census (UVC; 177 individual point counts) inside and outside the MPA over a 40-month period revealed that roman occurred in significantly higher densities and mean sizes inside the MPA (generalised linear models (GLM); $p<0.001){ }^{27}$ Sites chosen for comparisons were similar with respect to benthic growth, substratum types, topography and oceanographic conditions. ${ }^{30}$ Furthermore, age-at-maturity and age-at-sex-change were lower in the exploited area. The condition factor of roman was significantly lower inside the MPA than outside $\left(0.0283 \mathrm{~g} / \mathrm{cm}^{3}\right.$ versus $0.0295 \mathrm{~g} / \mathrm{cm}^{3}$; $p<0.001$ ), a probable sign of higher intraspecific competition. ${ }^{27}$

Apart from roman, 10 other reef fish species were landed by the boatbased fishery and could be considered secondary target species. However, catch frequencies of these species were less than $20 \%$ of the overall catch. Sample sizes were thus insufficient for the secondary target species to be assessed at the same level of detail as roman (i.e. life-history effects). However, this assessment may be possible elsewhere if catches are not dominated by one species. The effects of the MPA on the abundance of secondary target species and non-target species are important from a biodiversity conservation perspective and were considered in the following step of the framework (Step III).

The empirical findings reviewed here suggest that the Goukamma MPA is effective in protecting a spawning population of the main target species in the area. ${ }^{27}$ The results are not surprising as similar fishinginduced effects have been found elsewhere. ${ }^{14,16,55}$ What is noteworthy is that Goukamma is functional despite the rather small area of protected reef ${ }^{49}$ which is also continuous with unprotected habitat across the MPA boundary. Both of these factors can compromise a MPA's protective effect, ${ }^{15,56}$ but would be less important where the home range of the target species is small (see Step IV).

\section{Step III: Detecting ecosystem effects}

A MPA with its adjacent fished areas could be considered a largescale 'exclusion experiment' which makes it possible to measure the effects of fishing on the ecosystem as a whole. ${ }^{57}$ Higher densities of exploited species inside a MPA should have a measureable effect on other species within the ecosystem through interspecific interactions. Densities of species competing with the exploited species (competitors) should be lower inside the MPA when compared to the fished site. ${ }^{57,58}$ The opposite could be true for species which do not compete with the exploited species, given the likelihood that some compete for space and/ or food with the competitors. A failure to detect indirect effects when using adequate sampling methods can have two main reasons..$^{13}$ If changes in the abundance of the exploited species are relative rather than absolute, indirect effects do not necessarily follow. This situation can arise where abundance differentials across MPA boundaries rather than time-series are examined. Also, the lag-phase for indirect effects to be measurable after MPA establishment is significantly longer than that for direct effects. As a result, indirect effects may not be detected where time-series are too short or cross-boundary assessments are conducted too early after MPA establishment.

\section{Test case: Goukamma}

The differences between exploited and protected sites at Goukamma were not confined to the target species. ${ }^{29,30} \mathrm{GLMs}$ and multivariate analysis of controlled angling and UVC data also revealed significant differences in species diversity, abundance and size frequency of nontarget fish species. These findings were echoed by differences in benthic invertebrate community structure. Differential fishing pressure across the MPA boundary was the principle explanatory factor. Species that had various degrees of dietary overlap with roman, ${ }^{39}$ such as santer, dageraad (Chrysoblephus cristiceps), fransmadam (Boopsoidea inornata) and blue hottentot were less abundant inside the MPA. In contrast, herbivores and small benthic omnivores such as strepie (Sarpa salpa), blacktail (Diplodus capensis) and steentjie (Spondyliosoma emarginatum) were more common inside the MPA because their diets overlapped less with that of roman. Crinoids, the preferred prey of roman, were less abundant inside the MPA. There was also less algal cover inside the MPA, which was attributable to higher grazer (benthic omnivore) abundance. . $9,60^{5}$

In ecological communities, indirect effects are usually smaller in magnitude and more variable than direct effects. ${ }^{61}$ Consequently, few studies have revealed indirect effects of fishing on marine communities even around well-established MPAs. This dearth is partly because of the difficulties associated with separating fishing effects from auxiliary environmental factors in the presence of high levels of natural variability. MPA studies that investigated temperate reefs mainly report on fishinvertebrate interactions. ${ }^{62}$ At Goukamma, we were able to show how roman compete with other omnivorous fish within the same trophic guild through such fish-invertebrate interactions. This ability was possible because of a randomly stratified sampling design that took environmental factors into account, thereby reducing the variability in the data set. ${ }^{27}$ Furthermore, the small home ranges of the reef fish (see below) meant that indirect effects of fishing were spatially less diffused and changes within the reef community remained local.

\section{Step IV: Evaluating the potential for spillover of adult fishes}

The spatio-temporal behaviour of the exploited species has a profound effect on the functionality of a MPA. Theory predicts a density-dependent dispersal of fish, which should result in a measurable net export of 
fish out of the MPA into the surrounding fishing areas. ${ }^{63,64}$ However, for species with a high degree of site fidelity, a density increase might rather result in a change in physiological parameters such as condition factor or growth rate. In such cases there would be limited potential for spillover of adult fish. On the other hand, for more mobile species, a MPA could still be effective by providing refuge during crucial life-history events such as spawning aggregations.

\section{Test case: Goukamma}

Mark and recapture and acoustic telemetry studies of roman at three locations along the South African temperate coast, including the Goukamma MPA, indicated that post-recruit roman occupied home ranges between $1000 \mathrm{~m}^{2}$ and $3000 \mathrm{~m}^{2} .25,26$ Although these areas can expand to $10000 \mathrm{~m}^{2}$ for spawning females, most roman remained resident. Only a small percentage (6-9\%) relocated within a distance of less than $10 \mathrm{~km} .{ }^{25}$ Although it was not studied in similar detail, most of the other reef-associated species found in the area (all members of the sea bream family) have been reported to be resident. ${ }^{65,66}$ No indication of density-dependent movement effects were detected in any of the mark and recapture experiments on these species.

Taking into account life-history parameters, observed habitat distribution, abundance, size frequency, natural mortality and the effect of fishing on the age-at-sex-change determined at Goukamma, ${ }^{27}$ the effect of the Goukamma MPA on the roman population was simulated with a spatially explicit individual-based model. ${ }^{28}$ The individual trajectories of nearly two million fish over three generations were followed during a simulated implementation of the reserve after 18 years of moderate exploitation. In this simulation, parameters such as age-at-sex-change, abundance and size frequency returned to pristine values 10 years after the MPA was implemented. However, little adult 'spillover' into fished areas was predicted. Fishing mortality and recruitment were kept constant in the model, as the former was not known within the required resolution and the latter was considered to be a function of processes of larger magnitude. Possible boundary effects caused by larval spillover could therefore not be detected in this simulation. The site fidelity of roman makes it suitable to be protected effectively even within very small 'no take' MPAs.

Spillover of adult fish from MPAs into adjacent fishing grounds has been reported from tropical ${ }^{51,67-69}$ and temperate regions. ${ }^{52,70}$ The detection of spillover crucially relies on information on the movement behaviour of the target species. However, studying movement behaviour is logistically complex and expensive. At Goukamma, the small home range of roman reduced the complexity and costs of this task. The additional information on abundance, life history and habitat distribution allowed for realistic modelling of population recovery and spillover.

\section{Step V: Evaluating the potential for larval spillover}

Given a higher density of exploited species inside a MPA without adult netmigration into fished areas, the MPA would merely function as a refuge if no spawning were to take place inside its boundaries. If spawning occurs, the larval ecology in the case of pelagic spawners and the oceanographic patterns in and around the MPA, determine its potential to provide conservation or fishery benefits..$^{71}$ If no larval spillover was to occur, there would be conservation benefits from self-seeding through maintenance of biodiversity within the MPA. A prerequisite for larval spillover is a production differential of larvae between inside and outside the MPA. If there is larval spillover, fishery and conservation benefits can occur through connectivity to fished areas and other MPAs.

\section{Test case: Goukamma}

Courtship behaviour of roman during the spawning season ${ }^{72}$ was regularly observed during dives in the Goukamma area. ${ }^{50}$ Sampling during this period revealed that over a third of the mature roman $(N=136)$ were reproductively active with 'ripe', 'ripe-running' or 'spent' gonads. ${ }^{50} \mathrm{As}$ a result of the size difference of mature roman at Goukamma, mean gonad weights of female and male roman were higher for individuals inside ( $(9: 9.2 \mathrm{~g} ; 0: 4.9 \mathrm{~g}$ ) than outside ( $(+: 7.6 \mathrm{~g} ; \AA: 4.2 \mathrm{~g}$ ) the MPA. Although not studied in roman, a single large female carpenter (Argyrozona

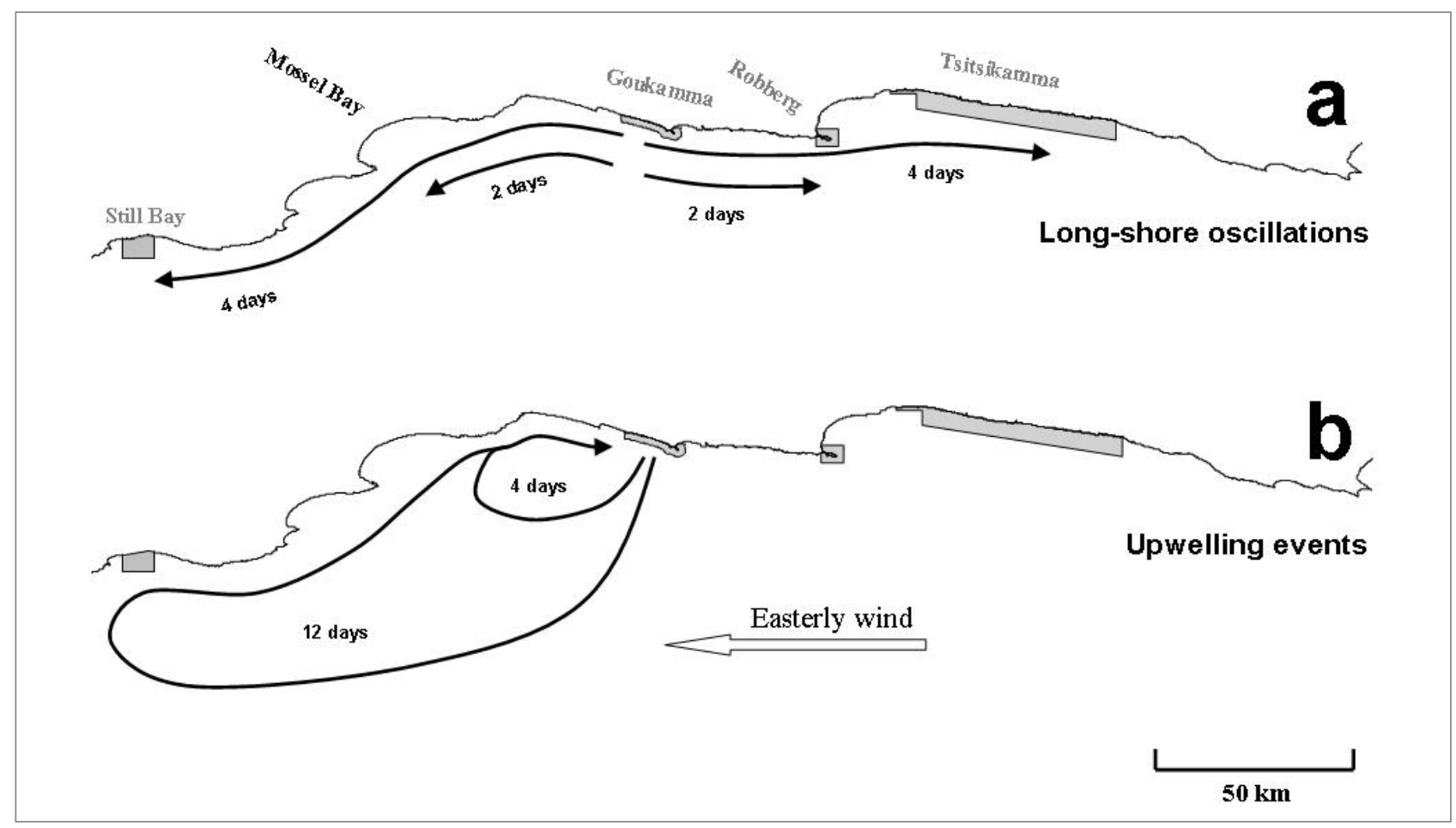

Figure 4: Projected distances of larval dispersal from the Goukamma marine protected area (MPA) into surrounding areas based on current patterns suggested by Tilney et al..$^{80}$ and Attwood et al. ${ }^{81}$ and mean current velocities measured in the MPA. Arrows indicate potential larval dispersal (a) during long-shore oscillations with periods of 2 to 4 days and (b) upwelling events caused by strong easterly winds lasting for periods between 4 and 12 days. Shaded areas show the positions of MPAs. 
argyrozona), a closely related species, will produce as many eggs as 72 small females during the same spawning season. ${ }^{73}$ Higher densities and more fecund roman inside the MPA are likely to translate into a larval production differential across the boundaries of the Goukamma MPA. ${ }^{28}$

The potential for larval spillover from a reserve decreases with reserve size and increases with larval dispersal scale. ${ }^{71}$ The dispersal scale depends on pelagic larval duration and current speed. ${ }^{74}$ According to in-situ rearing and morphological examinations, ${ }^{75,76}$ larvae of roman should drift passively in prevailing currents for about 17 days before they actively settle. Currents measured at Goukamma by holey-sock drogue deployments during the spawning season of roman suggested that passive transport across borders (bidirectional-longshore and offshore) would be achieved in time intervals from $5 \mathrm{~h}$ to 3 days. ${ }^{30}$

The potential of Goukamma MPA to export planktonic larvae of even sessile animal populations of short-distance dispersers was confirmed in a field study on brown mussel (Perna perna), which have a pelagic larval duration of about 15 days. ${ }^{77}$ The comparatively long pelagic larval duration of roman, the strong currents at Goukamma (mean current speed of $0.3 \mathrm{~m} / \mathrm{s}$ and maximum of $0.7 \mathrm{~m} / \mathrm{s}$ ) and the importance of connectivity between MPAs, ${ }^{78}$ indicate that an investigation into larger-scale oceanographic patterns and dispersal could reveal further conservation and fishery benefits through larval spillover.

Off the south coast of South Africa, two distinct current patterns occur during the spawning season of roman. ${ }^{79,80} \mathrm{~A}$ fairly regular long-shore current oscillation is caused by east-moving cyclones with periods of 2 to 4 days and upwelling events caused by strong easterly winds lasting for periods between 4 and 12 days. Projection of long-shore larval dispersal based on the mean current velocities for eastward and westward directions measured at Goukamma suggested connectivity to the Robberg and Tsitsikamma MPAs in the east and fishing grounds around Mossel Bay and the Still Bay MPA in the west (Figure 4a). The mean velocity for southward currents implied that upwelling could transport larvae between $20 \mathrm{~km}$ and $60 \mathrm{~km}$ offshore. As revealed from infrared satellite imagery, prevailing easterly winds push the cold water between $50 \mathrm{~km}$ and $250 \mathrm{~km}$ westwards and the onset of westerly winds then drives the water eastwards and inshore. As a result, larvae could be transported back to the Goukamma MPA, possibly re-seeding the area (Figure 4b).

A recent genetic analysis of roman along the South African south coast ${ }^{81}$ suggested a single well-mixed stock with no obvious change in genetic diversity from Cape Point (450 km west of Goukamma) to Port Alfred (350 km east of Goukamma). The authors concluded that dispersal in roman is 'bidirectional and of a magnitude sufficiently high to homogenize genetic structure' indicating connectivity between regional populations. Although not direct proof of larval dispersal from the Goukamma MPA, genetic analysis of marine populations as such constitute a valuable tool when assessing the dispersal of larvae from MPAs. ${ }^{82}$

Measuring larval dispersal remains one of the great challenges in MPA research. ${ }^{23,74,83}$ Research at Goukamma was no exception and led to the least conclusive evidence in the evaluation process of the MPA. Based on the oceanographic data and the limited information on the larval ecology of sea breams, the investigations presented indirect evidence for possible larval dispersal from the Goukamma MPA. This dispersal may happen over broad scales with potential for self-seeding and connectivity to other MPAs. ${ }^{81}$ To date, there is no direct evidence from field experiments for larval dispersal from MPAs in South Africa. The high degree of fish endemism along South Africa's coast makes the likelihood of larval recruitment back into natal populations greater. ${ }^{84}$ Nevertheless, there is a need for investigating and quantifying effects of larval dispersal using environmenta| ${ }^{85}$ and chemical tracers. ${ }^{86}$

\section{Step VI: Detecting effects on the fishery}

The establishment of MPAs is likely to cause a change of fishing patterns which may result in additional travel costs and initial loss of catches. To consider a MPA as a fisheries management option, one needs to calculate whether the long-term benefits of sustaining the fishery outweigh any short-term negative consequences for the fishers.
To evaluate this, spatial information on fisheries catches before and after MPA implementation are most useful. For MPAs this information is typically either not available or derived from fishery-dependent catch information. These are of varying spatial resolution and quality.

\section{Test case: Goukamma}

Fisheries data for the period 1985-1999 for the area within range of the launch sites of the commercial line boat fleet operating around Goukamma was analysed by one of us (Kerwath; unpublished data National Marine Linefish System). The data were examined with regard to changes in fishing patterns, effort and catch in kilograms (i.e. catch per unit effort, CPUE) per boat. A log-linear model with a truncated negative binomial distribution was employed as this model also accounts for potential overdispersion. ${ }^{87}$ Confidence intervals for CPUE were estimated using a non-parametric bootstrapping procedure. ${ }^{88}$

The model suggested a strong relationship between roman landings and CPUE as an indicator of availability of this resource to the fishery. Results indicated that there was no negative impact on the fishery in terms of increased travel distances as there was no change in spatial fishing patterns. Furthermore, no systematic change in targeting was evident. As expected from the research angling results, ${ }^{27}$ there was a steady improvement of standardised CPUE in the Goukamma area, which was elevated at sites directly adjacent to the reserve boundary. After 5 years, a period equivalent to the age of first recruitment of roman into the fishery, ${ }^{27}$ the increase became more pronounced. As predicted, an improvement of roman catches was not observed in other areas along the South African south coast.

The presence of spatial fisheries catch data at Goukamma from before and after MPA implementation has to be considered fortunate. The increase in standardised CPUE and landings of roman from 1995 onwards can best be explained by a combination of boundary effects and an increased reproductive output from the reserve and the resultant improvement of recruitment into the fishery. Not only did catch rates and roman landings increase after the establishment of the MPA, there was also no indication that fishers were displaced or had to change their fishing pattern. Although these results are still subject to verification, this observation was an important one which is still rarely considered in the conservation-oriented MPA literature..$^{17,21}$

\section{Discussion}

Convincing empirical evidence that can ascribe even relatively simple effects, such as differences in abundance between MPAs and exploited areas to differential exploitation, is still rare..$^{15,22,89}$ By investigating a set of key questions, we were able to show that the exclusion of fishing boats from Goukamma had an overall beneficial effect which manifested itself in a recovery of the species that had been the main target within the MPA, which in turn had positive effects on the maintenance of ecosystem functioning inside the MPA and an improved fishery yield outside its boundaries.

Most of the individual issues identified here have been examined in numerous MPAs around the world, ${ }^{5}$ but only in combination can they be used to support or refute the effectiveness of a MPA. This complex task required a framework that could be followed during an assessment. Although such frameworks already exist, existing frameworks were designed to be generally applicable ${ }^{35,36}$ and can therefore lack the necessary methodological detail required in the process. Other frameworks focused on different aspects of MPA assessments, such as management efficiency ${ }^{31}$ and economic value ${ }^{34}$ or used mathematical models to describe the trade-offs between conservation and fishery benefits. ${ }^{90}$ In this contribution, we proposed and followed a practical step-by-step guide that would be generally applicable to MPAs that aim to derive their benefits mainly from exclusion of exploitation. We acknowledge that there are other mechanisms, for example the exclusion of habitat disturbance through diving and boating or specific protection from marine pollution, which are not covered here. In the case of Goukamma, a medium-sized MPA where the exclusion of boat-based fishing was aimed at protecting temperate reef habitat, the framework 
was adequate to detect a positive effect on biodiversity conservation and fishery management. The framework may help to identify and fill gaps in the knowledge around similar MPAs with similar objectives and make MPA assessments more rigorous. A more general applicability could be tested using MPAs of different sizes, representative of the various biogeographic regions, habitats, marine resources and extractive users in South Africa and elsewhere.

The history of MPAs in South Africa was not out of step with developments elsewhere. The expansion of MPAs into the offshore realm has brought conservation and fisheries management into further confrontation, which calls for a more rigorous approach to the assessment of the effectiveness of this management tool against more traditional, speciesspecific conservation and management approaches.

\section{Acknowledgements}

This project was funded in part by the National Research Foundation (South Africa) and the Marine Living Resources Fund. The Elwandle Node of the South African Environmental Observation Network provided additional assistance.

\section{Authors' contributions}

A.G. and S.E.K. designed and executed the experiments. C.G.A. contributed to the design of the experiments.

\section{References}

1. Bohnsack JA, Ault JS. Management strategies to conserve marine biodiversity. Oceanography. 1996;9:73-82. http://dx.doi.org/10.5670/ oceanog.1996.30

2. Clark CW. Marine reserves and the precautionary management of fisheries. Ecol Appl. 1996;6:369-370. http://dx.doi.org/10.2307/2269374

3. Roberts CM. Ecological advice on the global fisheries crisis. Trends Ecol Evol. 1997;12:35-38. http://dx.doi.org/10.1016/S0169-5347(96)20109-0

4. Guénette S, Pitcher TJ. An age-structured model showing the benefits of marine reserves in controlling overexploitation. Fish Res. 1999;39:295303. http://dx.doi.org/10.1016/S0165-7836(98)00173-8

5. Gell FR, Roberts CM. The fishery effects of marine reserves and fishery closures. Washington, DC: World Wildlife Fund; 2003.

6. García-Charton JA, Pérez-Ruzafa A, Marcos C, Claudet J, Badalamenti F Benedetti-Cecchi $L$, et al. Effectiveness of European Atlanto-Mediterranean MPAs: Do they accomplish the expected effects on populations, communities and ecosystems? J Nat Conserv. 2008:16:193-221. http:// dx.doi.org/10.1016/j.jnc.2008.09.007

7. Pérez-Ruzafa Á, Marcos C, García-Charton JA, Salas F. European marine protected areas (MPAs) as tools for fisheries management and conservation. J Nat Conserv. 2008;16:187-192. http://dx.doi.org/10.1016/j. jnc.2008.09.008

8. Margules CR, Pressey RL. Systematic conservation planning. Nature. 2000;405:243-253. http://dx.doi.org/10.1038/35012251

9. Grantham HS, Moilanen A, Wilson KA, Pressey RL, Rebelo TG, Possingham HP. Diminishing return on investment for biodiversity data in conservation planning. Conserv Lett. 2008;1:190-198. http://dx.doi.org/10.1111/j.1755263X.2008.00029.X

10. Klein CJ, Steinback C, Scholz AJ, Possingham HP. Effectiveness of marine reserve networks in representing biodiversity and minimizing impact to fishermen: A comparison of two approaches used in California. Conserv Lett. 2008;1:44-51. http://dx.doi.org/10.1111/j.1755-263X.2008.00005.x

11. Hilborn R, Arcese P, Borner M, Hando J, Hopcraft G, Loibooki M, et al. Effective enforcement in a conservation area. Science. 2006;314:1266. http://dx.doi.org/10.1126/science.1132780

12. Willis TJ, Millar RB, Babcock RC, Tolimieri N. Burdens of evidence and the benefits of marine reserves for fishery management: Putting Descartes before des horse? Environ Conserv. 2003;30:97-103. http://dx.doi. org/10.1017/S0376892903000092

13. Babcock RC, Shears NT, Alcala AC, Barrett NS, Edgar GJ, Lafferty KD, et al. Decadal trends in marine reserves reveal differential rates of change in direct and indirect effects. Proc Natl Acad Sci USA. 2010;107:18256-18261. http://dx.doi.org/10.1073/pnas.0908012107
14. Mosqueira I, Côté IM, Jennings S, Reynolds JD. Conservation benefits of marine reserves for fish populations. Anim Conserv. 2000;3:321-332. http://dx.doi.org/10.1111/j.1469-1795.2000.tb00117.x

15. Halpern BS. The impact of marine reserves: Do reserves work and does reserve size matter? Ecol Appl. 2003;13:117-137. http://dx.doi. org/10.1890/1051-0761(2003)013[0117:TIOMRD]2.0.C0;2

16. Lester SE, Halpern BS, Grorud-Colvert K, Lubchenco J, Ruttenberg BI, Gaines SD, et al. Biological effects within no-take marine reserves: A global synthesis. Mar Ecol Progr Ser. 2009;384:33-46. http://dx.doi.org/10.3354/ meps08029

17. Hilborn R, Stokes K, Maguire J-J, Smith TL, Botsford W, Mangel M, etal. When can marine reserves improve fisheries management? Ocean Coast Manage. 2004;47:197-205. http://dx.doi.org/10.1016/j.ocecoaman.2004.04.001

18. Degnbol P, Gislason H, Hanna S, Jentoft S, Nielsen JR, Sverdrup-Jensen $S$, et al. Painting the floor with a hammer: Technical fixes in fisheries management. Mar Policy. 2006;30:534-543. http://dx.doi.org/10.1016/j. marpol.2005.07.002

19. Nowlis JS, Roberts CM. Fisheries benefits and optimal design of marine reserves. Fish Bull. 1999:97:604-616.

20. Hastings A, Botsford LW. Comparing design of marine reserves for fisheries and for biodiversity. Ecol Appl. 2003;13:65-70. http://dx.doi. org/10.1890/1051-0761(2003)013[0065:CDOMRF]2.0.C0;2

21. Kaiser MJ. Are marine protected areas a red herring or fisheries panacea? Can J Fish Aquat Sci. 2005;62:1194-1199. http://dx.doi.org/10.1139/f05056

22. Willis TJ, Millar RB, Babcock RC. Protection of exploited fish in temperate regions: High density and biomass of snapper Pagrus auratus (Sparidae) in northern New Zealand marine reserves. J Appl Ecol. 2003;40:214-227. http://dx.doi.org/10.1046/j.1365-2664.2003.00775.x

23. Sale PF, Cowen RK, Danilowicz BS, Jones GP, Kritzer JP, Lindeman KC, et al Critical science gaps impede use of no-take fishery reserves. Trends Ecol Evol. 2005;20:74-80. http://dx.doi.org/10.1016/j.tree.2004.11.007

24. Gaines SD, White C, Carr MH, Palumbi SR. Designing marine reserve networks for both conservation and fisheries management. Proc Natl Acad Sci. 2010;107:18286-18293. http://dx.doi.org/10.1073/pnas.0906473107

25. Kerwath SE, Götz A, Attwood CG, Cowley PD, Sauer WHH. Movement pattern and home range of roman Chrysoblephus laticeps. Afr J Mar Sci. 2007;29:93-103. http://dx.doi.org/10.2989/AJMS.2007.29.1.8.73

26. Kerwath SE, Götz A, Attwood CG, Sauer WHH. Area utilization and activity patterns of roman Chrysoblephus laticeps (Sparidae) in a small marine protected area. Afr J Mar Sci. 2007;29:259-270. http://dx.doi.org/10.2989/ AJMS.2007.29.2.10.193

27. Götz A, Kerwath SE, Attwood CG, Sauer WHH. Effects of fishing on population structure and life history of roman Chrysoblephus laticeps (Sparidae). Mar Ecol Progr Ser. 2008;362:245-259. http://dx.doi.org/10.3354/meps07410

28. Kerwath SE, Götz A, Attwood CG, Sauer WHH. The effect of marine protected areas on an exploited population of sex-changing temperate ree fish: An individual-based model. Afr J Mar Sci. 2008;30:337-350. http:// dx.doi.org/10.2989/AJMS.2008.30.2.10.560

29. Götz A, Kerwath SE, Attwood CG, Sauer WHH. Effects of fishing on a temperate reef community in South Africa 2: Benthic invertebrates and algae. Afr J Mar Sci. 2009;31:253-262. http://dx.doi.org/10.2989/ AJMS.2009.31.2.13.885

30. Götz A, Kerwath SE, Attwood CG, Sauer WHH. Effects of fishing on a temperate reef community in South Africa I: Ichthyofauna. Afr J Mar Sci. 2009;31: 241-251. http://dx.doi.org/10.2989/AJMS.2009.31.2.12.884

31. Alder J, Zeller D, Pitcher T, Sumaila R. A method for evaluating marine protected area management. Coast Manage. 2002;30:121-131. http:// dx.doi.org/10.1080/08920750275350466

32. Ervin J. Rapid assessment and prioritization of protected area management (RAPPAM) methodology. Gland, Switzerland: World Wildlife Fund; 2003.

33. Staub F, Hatziolos ME. Score card to assess progress in achieving management effectiveness goals for marine protected areas. Washington, DC: The World Bank; 2004.

34. Grafton $R Q$, Akter S, Kompas T. A policy-enabling framework for the ex-ante evaluation of marine protected areas. Ocean Coast Manage. 2011;54:478-487. http://dx.doi.org/10.1016/j.ocecoaman.2011.03.006

35. Kelleher G. Guidelines for marine protected areas., Gland, Switzerland and Cambridge, UK: International Union for Conservation of Nature; 1999. 
36. Pomeroy R, Parks J, Watson L. How is your MPA doing? A guidebook of natural and social indicators for evaluating marine protected area management effectiveness. Gland, Switzerland and Cambridge, UK: International Union for Conservation of Nature; 2004.

37. Flemming BW, Eagle GA, Fricke AH, Hunter IT, Martin IT, Schumann EH, et al. Agulhas Bank studies. Stellenbosch: National Research Institute for Oceanology; 1983.

38. Zoutendyk P, Duvenage IR. Composition and biological implications of a nepheloid layer over the inner Agulhas Bank near Mossel Bay, South Africa. T Roy Soc S Afr. 1989;47:187-197. http://dx.doi. org/10.1080/00359198909520162

39. Buxton CD. Feeding biology of the Roman Chrysoblephus laticeps (Pisces: Sparidae). S Afr J Mar Sci. 1984;2:33-42. http://dx.doi. org/10.2989/02577618409504356

40. Pradervand P, Hiseman R. An analysis of the recreational shore fishery in the Goukamma Marine Protected Area. Afr Zool. 2006;41:275-285. http:// dx.doi.org/10.3377/1562-7020(2006)41[275:AAOTRS]2.0.C0;2

41. Department of Agriculture, Forestry and Fisheries (DAFF). Status of the South African marine fishery resources: 2010 annual report. Cape Town: Fisheries Branch of the Department of Agriculture, Forestry and Fisheries; 2010.

42. Jennings S, Marshall SS, Polunin NVC. Seychelles' marine protected areas: Comparative structure and status of reef fish communities. Biol Conserv. 1996;75:201-209. http://dx.doi.org/10.1016/0006-3207(95)00081-X

43. Attwood CG, Harris JM, Williams AJ. International experience of marine protected areas and their relevance to South Africa. S Afr J Mar Sci. 1997;18:311-332. http://dx.doi.org/10.2989/025776197784161162

44. Attwood CG, Mann BQ, Beaumont J, Harris JM. Review of the state of marine protected areas in South Africa. S Afr J Mar Sci. 1997;18:341-367. http://dx.doi.org/10.2989/025776197784160910

45. Roberts CM. Selecting marine reserve locations: optimality versus opportunism. Bull Mar Sci. 2000;66:581-592.

46. Rogers CS, Beets J. Degradation of marine ecosystems and decline of fishery resources in marine protected areas in the US Virgin Islands. Environ Conserv. 2001;28:312-322. http://dx.doi.org/10.1017/ S0376892901000340

47. Kritzer JP. Effects of noncompliance on the success of alternative designs of marine protected area networks for conservation and fisheries management. Conserv Biol. 2004;18:1021-1031. http://dx.doi.org/10.1111/j.15231739.2004.00022.x

48. Kendall MS, Eschelbach KA, McFall G, Sullivan J, Bauer L. MPA design using sliding windows: Case study designating a research area. Ocean Coast Manage. 2008;51:815-825. http://dx.doi.org/10.1016/j. ocecoaman.2008.09.004

49. Götz A, Kerwath SE, Attwood CG, Sauer WHH. A change of the seaward boundary of Goukamma Marine Protected Area could increase conservation and fishery benefits. S Afr J Sci. 2009;105:330-331.

50. Götz A. Assessment of the effect of Goukamma Marine Protected Area on community structure and fishery dynamics [PhD thesis]. Grahamstown: Rhodes University; 2005

51. McClanahan TR, Mangi S. Spillover of exploitable fishes from a marine park and its effect on the adjacent fishery. Ecol Appl. 2000;10:1792-1805. http:// dx.doi.org/10.1890/1051-0761(2000)010[1792:SOEFFA]2.0.C0;2

52. Goñi R, Adlerstein S, Alvarez-Berastegui D, Forcada A, Reñones 0, Criquet $G$, et al. Spillover from six western Mediterranean marine protected areas: Evidence from artisanal fisheries. Mar Ecol Progr Ser. 2008;366:159-174. http://dx.doi.org/10.3354/meps07532

53. Hawkins JP, Roberts CM. Effects of fishing on sex-changing Caribbean parrotfishes. Biol Conserv. 2004;115:213-226. http://dx.doi.org/10.1016/ S0006-3207(03)00119-8

54. Claudet J, Osenberg CW, Benedetti-Cecchi L, Domenici P, García-Charton JA, Pérez-Ruzafa A, et al. Marine reserves: size and age do matter. Ecol Lett. 2008;11:481-489. http://dx.doi.org/10.1111/j.1461-0248.2008.01166.x

55. Halpern BS, Warner RR. Marine reserves have rapid and lasting effects. Ecol Lett. 2002;5:361-366. http://dx.doi.org/10.1046/j.14610248.2002.00326.x
56. Roberts CM, Andelman S, Branch GM, Bustamante RH, Castilla JC, Dugan J, et al. Ecological criteria for evaluating candidate sites for marine reserves. Ecol Appl. 2003;13:199-214. http://dx.doi.org/10.1890/10510761(2003)013[0199:ECFECS]2.0.C0;2

57. Walters CJ, Holling CS. Large-scale management experiments and learning by doing. Ecology. 1990;71:2060-2068. http://dx.doi.org/10.2307/1938620

58. Pinnegar JK, Polunin NVC, Francour P, Badalamenti F, Chemello R, HarmelinVivien $M-L$, et al. Trophic cascades in benthic marine ecosystems: lessons for fisheries and protected-area management. Environ Conserv. 2000;27:179-200. http://dx.doi.org/10.1017/S0376892900000205

59. Antolić B, Skaramuca B, Špan A, Mušin D, Sanko-Njire J. Food and feeding habits of a herbivore fish Sarpa salpa (L.) in the southern Adriatic (Croatia). Acta Adriat. 1994;35:45-52.

60. Havelange S, Lepoint G, Dauby P, Bouquegneau JM. Feeding of the sparid fish Sarpa salpa in a seagrass ecosystem: Diet and carbon flux. Mar Ecol PSZNI. 1997;18:289-297. http://dx.doi.org/10.1111/j.1439-0485.1997. tb00443.x

61. Menge BA. Indirect effects in marine rocky intertidal interaction webs: Patterns and importance. Ecol Monogr. 1995;65:21-74. http://dx.doi. org/10.2307/2937158

62. Shears NT, Babcock RC. Marine reserves demonstrate top-down controls of community structure on temperate reefs. Oecologia. 2002;132:131-142. http://dx.doi.org/10.1007/s00442-002-0920-x

63. DeMartini EE. Modelling the potential of fishery reserves for managing Pacific coral reef fishes. Fish Bull. 1993;91:414-427.

64. Attwood CG, Bennett BA. Variation in dispersal of galjoen (Coracinus capensis) (Teleostei: Coracinidae) from a marine reserve. Can J Fish Aquat Sci. 1994;51:1247-1257. http://dx.doi.org/10.1139/194-124

65. Buxton CD, Smale MJ. Abundance and distribution patterns of three temperate reef fishes (Teleostei: Sparidae) in exploited and unexploited areas off the southern Cape coast. J Appl Ecol. 1990;26:441-451. http:// dx.doi.org/10.2307/2404072

66. Mann BQ South African marine linefish status reports. Oceanographic Research Institute Special Publication No. 7. Durban: Oceanographic Research Institute; 2000.

67. Zeller D, Stoute SL, Russ GR. Movements of reef fishes across marine reserve boundaries: Effects of manipulating a density gradient. Mar Ecol Progr Ser. 2003;254:269-280. http://dx.doi.org/10.3354/meps254269

68. Abesamis RA, Russ GR. Density-dependent spillover from a marine reserve: Long-term evidence. Ecol Appl. 2005;15:1798-1812. http://dx.doi. org/10.1890/05-0174

69. Ashworth JS, Ormond RFG. Effects of fishing pressure and trophic group on abundance and spillover across boundaries of a no-take zone. Biol Conserv. 2005;121:333-344. http://dx.doi.org/10.1016/j.biocon.2004.05.006

70. Stobart B, Warwick R, González C, Mallol S, Díaz D, Reñones 0, et al. Long-term and spillover effects of a marine protected area on an exploited fish community. Mar Ecol Progr Ser. 2009;384:47-60. http://dx.doi. org/10.3354/meps08007

71. Pelc RA, Warner RR, Gaines SD, Paris CB. Detecting larval export from marine reserves. Proc Natl Acad Sci USA. 2010;107:18266-18271. http:// dx.doi.org/10.1073/pnas.0907368107

72. Buxton CD. Reproductive biology of Chrysoblephus laticeps and C cristiceps (Teleostei: Sparidae). J Zool. 1990;220:497-511. http://dx.doi. org/10.1111/j.1469-7998.1990.tb04321.x

73. Brouwer SL, Griffiths CL, Roberts MJ. Adult movement and larval dispersal of Argyrozona argyrozona (Pisces: Sparidae) from a temperate marine protected area. S Afr J Mar Sci. 2003;25:395-402. http://dx.doi. org/10.2989/18142320309504028

74. Gaines SD, Gaylord B, Largier JL. Avoiding current oversights in marine reserve design. Ecol Appl. 2003;12:32-46. http://dx.doi.org/10.1890/10510761(2003)013[0032:ACOIMR]2.0.C0;2

75. Brownell CL. Water quality requirements for first-feeding in marine fish larvae of the Cape of Good Hope with descriptions of developmental stages [PhD thesis]. Cape Town: University of Cape Town; 1979.

76. Davis JA. Investigations into the larval rearing of two South African sparid species [MSc thesis]. Grahamstown: Rhodes University; 1997. 
77. Pelc RA, Baskett ML, Tanci T, Gaines SD, Warner RR. Quantifying larval export from South African marine reserves. Mar Ecol Progr Ser. 2009;394:65-78.

78. Sala E, Aburto-Oropeza 0, Paredes G, Parra I, Barrera JC, Dayton PK. A general model for designing networks of marine reserves. Science. 2002;298:1991-1993.

79. Tilney RL, Nelson G, Radloff SE, Buxton CD. Ichthyoplankton distribution and dispersal in the Tsitsikamma National Park marine reserve, South Africa. S Afr J Mar Sci. 1996;17:1-14.

80. Attwood CG, Allen JC, Claassen PJ. Nearshore surface current patterns in the Tsitsikamma National Park, South Africa. S Afr J Mar Sci. 2002;24:151-160.

81. Teske PR, Forget FRG, Cowley PD, Von der Heyden S, Beheregaray LB. Connectivity between marine reserves and exploited areas in the philopatric reef fish Chrysoblephus laticeps (Teleostei: Sparidae). Mar Biol. 2010;157:2029-2042. http://dx.doi.org/10.1007/s00227-010-1471-z

82. Palumbi SR. Population genetics, demographic connectivity, and the design of marine reserves. Ecol Appl. 2003:13:146-158. http://dx.doi. org/10.1890/1051-0761(2003)013[0146:PGDCAT]2.0.C0;2

83. Planes S, Galzin R, Garcia-Rubies A, Goñi R, Harmelin J-G, Le Diréach $\mathrm{L}$, et al. Effects of marine protected areas on recruitment processes with special reference to Mediterranean littoral ecosystems. Environ Conserv. 2000;27:126-143. http://dx.doi.org/10.1017/S0376892900000175
84. Swearer SE, Shima JS, Hellberg ME, Thorrold SR, Jones GP, Robertson DR, et al. Evidence of self-recruitment in demersal marine populations. Bull Mar Sci. 2002;70:251-271.

85. Patterson HM, Swearer SE. Long-distance dispersal and local retention of larvae as mechanisms of recruitment in an island population of a coral reef fish. Austral Ecol. 2007;32:122-130. http://dx.doi.org/10.1111/j.14429993.2006.01669.x

86. Jones GP, Planes S, Thorrold SR. Coral reef fish larvae settle close to home. Curr Biol. 2005;15:1314-1318. http://dx.doi.org/10.1016/j. cub.2005.06.061

87. McCullagh P, Nelder JA. Generalized linear models. 2nd edition. London: Chapman and Hall; 1989.

88. Efron B, Tibshirani R. Bootstrap methods for standard errors, confidence intervals, and other measures of statistical accuracy. Stat Sci. 1986;1:5477. http://dx.doi.org/10.1214/ss/1177013815

89. Russ GR, Alcala AC, Maypa AP, Calumpong HP, White AT. Marine reserve benefits local fisheries. Ecol Appl. 2004;14:597-606. http://dx.doi. org/10.1890/03-5076

90. Levin PS, Kaplan I, Grober-Dunsmore R, Chittaro PM, Oyamada S, Andrews $\mathrm{K}$, et al. A framework for assessing the biodiversity and fishery aspects of marine reserves. J Appl Ecol. 2009;46:735-742. http://dx.doi.org/10.1111/ j.1365-2664.2009.01667.x 